\title{
PREVALENCIJA INVALIDITETA UZROKOVANOG OŠTEĆENJEM SLUHA U REPUBLICI HRVATSKOJ
}

\author{
ŽELJKA DRAUŠNIK ${ }^{1}$, VESNA ŠTEFANČIĆ ${ }^{1}$, TOMISLAV BENJAK ${ }^{1}$ \\ ${ }^{1}$ Hrvatski zavod za javno zdravstvo, 10000 Zagreb, kontakt: zeljka.drausnik@hzjz.hr
}

Primljeno: 27.10.2015.

Stručni rad

Prihvaćeno: 17.2.2015.

UDK: $376.1-056.263$

Sažetak: U Republici Hrvatskoj se, u Registru osoba s invaliditetom prati broj osoba s oštećenjem sluha kod kojih je utvrđen invaliditet temeljem tog oštećenja. Podatke u Registar dostavlja Zavod za vještačenje, profesionalnu rehabilitaciju i zapošljavanje osoba s invaliditetom. Prema Registru, u Hrvatskoj živi 13609 osoba čiji je invaliditet uzrokovan oštećenjem sluha (0,32\%), no uspoređujući taj podatak s podacima međunarodnih istraživanja nailazimo na velike razlike. Podaci o prevalenciji oštećenja sluha u svijetu pokazuju 16 puta veću učestalost od one trenutno evidentirane u Registru. Ostale međunarodne procjene također upućuju na veću prevalenciju oštećenja sluha nego što je zabilježena u Hrvatskoj. Jedan od glavnih razloga ovakvih razlika raspon je oštećenja sluha koji se uzima u obzir. U hrvatskom registru prati se broj osoba kod kojih je oštećenje sluha dovelo do invaliditeta, dok međunarodna istraživanja obuhvaćaju i blaža oštećenja koja ne dovode do invaliditeta. Drugi, jednako bitan, razlog jest činjenica da se međunarodna istraživanja temelje na procjenama, dok se za Hrvatsku koriste točni podaci prikupljeni putem rješenja o invaliditetu.

Ključne riječi: oštećenje sluha, prevalencija invaliditeta, Registar osoba s invaliditetom

\section{UVOD}

Prevalencija oštećenja sluha u svijetu iznosi preko 5\%, odnosno obuhvaća 360 milijuna ljudi, od čega 328 milijuna odraslih (183 milijuna muškaraca i 145 milijuna žena) i 32 milijuna djece (WHO, 2012). Ovaj podatak obuhvaća oštećenje sluha od $40 \mathrm{~dB}$ na uhu s boljim ostacima sluha kod odraslih, odnosno 30dB kod djece (WHO, 2012). Prema podacima SZO prevalencija oštećenja sluha je u zemljama s niskim dohotkom oko dva puta veća od prevalencije u zemljama s visokim dohotkom, a vidljiv je i porast prevalencije s dobi - u djece iznosi $1,7 \%$, u osoba iznad 15 godina je $7 \%$, a svaka treća osoba na svijetu starija od 65 godina ima oštećenja sluha (WHO global estimates on prevalence of hearing loss; Mortality and Burden of Diseases and Prevention of Blindness and Deafness, 2012) (Tablica 1).

Ovisno o težini i dobi u kojoj je nastalo, oštećenje sluha može utjecati na mnoge važne aspekte života pojedinca, poput razvoja govora, procesa učenja, profesionalnog i društvenog života, a može potencirati i stigmatizaciju ovih osoba (Škrbić i sur., 2013, Dobie i Van Hemel, 2004, Al-Mahbashi i Raja'a, 2011, Shield, 2006). Oštećenja sluha ima značajne ekonomske i socijalne implikacije zbog visoke prevalencije, naročito u osoba treće životne dobi. Ono također utječe na radnu sposobnost pojedinca i kvalitetu njegova života općenito. Uz to, dodjela slušnih pomagala predstavlja značajan izdatak za zdravstveni sustav društva (Shield, 2006).

Hrvatski zavod za javno zdravstvo (HZJZ) putem Registra osoba s invaliditetom (ROI) prati kretanje broja osoba s oštećenjem sluha, ali samo onih osoba kod kojih je utvrđen invaliditet temeljem tog oštećenja. Kriteriji po kojem osobe s oštećenjem sluha imaju invaliditet i upisuju se u ROI određeni su Uredbom o metodologijama vještačenja (NN, 153/14) Ti kriteriji su slijedeći:

- gluhoća - gubitak sluha veći od 93\% po Fowleru s komunikacijskim teškoćama

- obostrano teško oštećenje sluha od $90 \%$ do 93\% po Fowleru s komunikacijskim teškoćama

- obostrana teška nagluhost s ukupnim gubitkom sluha od $70 \%$ do $90 \%$ po Fowleru s 
Tablica 1. Globalne procjene o prevalenciji oštećenja sluha

\begin{tabular}{|c|c|c|c|c|c|c|}
\hline \multirow[t]{3}{*}{ Regija svijeta } & \multirow{2}{*}{\multicolumn{2}{|c|}{$\begin{array}{c}\begin{array}{c}\text { oštećenja sluha koja } \\
\text { uzrokuju invaliditet } \mathbf{u} \\
\text { djece }\end{array} \\
\text { oba spola } \\
\end{array}$}} & \multicolumn{4}{|c|}{ oštećenja sluha koja uzrokuju invaliditet u odraslih } \\
\hline & & & \multicolumn{2}{|c|}{ muškarci } & \multicolumn{2}{|c|}{ žene } \\
\hline & milijuna & $\begin{array}{c}\text { prevalencija } \\
(\%)\end{array}$ & milijuna & $\begin{array}{c}\text { prevalencija } \\
(\%)\end{array}$ & milijuna & $\begin{array}{c}\text { prevalencija } \\
(\%)\end{array}$ \\
\hline Zemlje visokog dohotka & 0.8 & 0,5 & 19 & 4,9 & 18 & 4,4 \\
\hline $\begin{array}{l}\text { Središnja i istočna Europa i središnja } \\
\text { Azija }\end{array}$ & 1.1 & 1,6 & 14 & 9,0 & 16 & 8,8 \\
\hline Subsaharska Afrika & 6.8 & 1,9 & 17 & 7,4 & 13 & 5,5 \\
\hline Bliski istok i sjeverna Afrika & 1.2 & 0,9 & 6 & 4,1 & 4 & 2,9 \\
\hline Južna Azija & 12.3 & 2,4 & 52 & 9,5 & 36 & 7,0 \\
\hline Pacifik & 3.4 & 2,0 & 19 & 8,7 & 15 & 6,8 \\
\hline Latinska Amerika i Karibi & 2.6 & 1,6 & 15 & 7,6 & 13 & 6,0 \\
\hline Istočna Azija & 3.6 & 1,3 & 41 & 7,4 & 30 & 5,6 \\
\hline SVIJET & 31.9 & 1,7 & 183 & 7,5 & 145 & 5,9 \\
\hline
\end{tabular}

Preuzeto s: WHO global estimates on prevalence of hearing loss; Mortality and Burden of Diseases and Prevention of Blindness and Deafness (WHO, 2012.)

komunikacijskim teškoćama

- obostrana teška nagluhost s ukupnim gubitkom sluha od $60 \%$ do $70 \%$ po Fowleru s komunikacijskim teškoćama

- obostrana teška nagluhost s ukupnim gubitkom sluha od $50 \%$ do $60 \%$ po Fowleru s komunikacijskim teškoćama

- postojanje nekompenzirane pareze vestibularnog aparata, jednog uha

- postojanje nekompenzirane paralize vestibularnog aparata, jednog uha

- postojanje nekompenzirane pareze vestibularnog aparata, oba uha

- gubitak jedne ušne školjke s komunikacijskim teškoćama

- gubitak ušne školjke oba uha s komunikacijskim teškoćama

Budući da Registar osoba s invaliditetom ne obuhvaća sve osobe s oštećenjem sluha u RH, podaci o broju registriranih osoba s oštećenjem sluha u nas znatno se razlikuju od podataka koji se navode u svijetu.

Stoga je cilj ovog rada ukazati upravo na veliku podregistraciju osoba s oštećenjem sluha u RH, na različite metodologije prikupljanja podataka u $\mathrm{RH} i$ u svijetu, zbog čega niti međunarodna usporedivost ovih podataka nije moguća, te pružiti prijedloge za moguće poboljšanje situacije. Krajnji cilj tih promjena jest unapređenje pozicije osoba s oštećenjem sluha u društvu, odnosno kvalitetnije zadovoljavanje njihovih potreba.

\section{HRVATSKI REGISTAR OSOBA S INVALIDITETOM}

Prema Zakonu o Hrvatskom registru o osobama s invaliditetom, invaliditet je trajno ograničenje, smanjenje ili gubitak sposobnosti (koje proizlazi iz oštećenja zdravlja) za neku fizičku aktivnost ili psihičku funkciju primjerenu životnoj dobi osobe i odnosi se na sposobnosti u obliku složenih aktivnosti i ponašanja, koje su općenito prihvaćene kao bitni dijelovi svakodnevnog života (NN, 64/01). Prema Zakonu o Hrvatskom registru o osobama s invaliditetom, oštećenje sluha dijeli se na gluhoću i nagluhost (NN, 64/01) pri čemu su kriteriji za upis u Registar definirani gore navedenom Uredbom.

Podatke u Registar, temeljem Zakona o registru osoba s invaliditetom (NN, 64/01) dostavljaju liječnici primarne zdravstvene zaštite, liječnici specijalisti školske medicine i liječnici specijalističko-konzilijarne zdravstvene zaštite, Ministarstvo socijalne politike i mladih uz pripadajuće centre za socijalnu skrb, gradski i županijski uredi nadležni za poslove obrazovanja, Ministarstvo znanosti, obrazovanja i sporta, Ministarstvo branitelja, Hrvatski zavod za mirovinsko osiguranje, no od 01.01.2015. uspostavom jedinstvenog tijela vještačenja jedini izvor podataka postaje Zavod za 
vještačenje, profesionalnu rehabilitaciju i zapošljavanje osoba s invaliditetom. Ovaj Zavod obavlja vještačenje $u$ prvom i drugom stupnju u postupcima ostvarivanja prava iz područja socijalne skrbi, mirovinskog osiguranja, zdravstva, obrazovanja, profesionalne rehabilitacije i zapošljavanja osoba s invaliditetom, zaštite ratnih i civilnih žrtava rata, te iz drugih područja u kojima se ostvaruju određena prava na temelju vještačenja. Vještačenje invaliditeta, a samim time i oštećenja sluha, provodi se na temelju Uredbe o metodologiji vještačenja (NN 153/14).

Prema 10. reviziji međunarodne klasifikacije bolesti i srodnih zdravstvenih problema (MKB-10), poremećaji slušanja dijele se na konduktivne, perceptivne i mješovite (MKB-10, 2012). Konduktivni poremećaji nastaju kao posljedica otežanog provođenja zvuka u vanjskom ili srednjem uhu, dok su perceptivni poremećaji posljedica oštećenja u unutarnjem uhu, slušnim živcima, te središnjem živčanom sustavu.

Uzroci oštećenja sluha koji dovode do invaliditeta, u Registru su sljedeće MKB-10 skupine dijagnoza: H60-H62 (Bolesti vanjskog uha), H65H75 (Bolesti srednjeg uha i mastoida), H80-H83 (Bolesti unutarnjeg uha), H90-H95 (Ostali poremećaji uha) te S08-09 (Ozljede). U tablici 2 je detaljno prikazano koje dijagnoze spadaju pod koju od navedenih skupina.

Prema Registru osoba s invaliditetom, $\mathrm{u}$ RH živi 508339 osoba s invaliditetom, što čini 11,86\% sveukupnog stanovništva RH, a od čega je za 13 609 osoba uzrok invaliditeta oštećenje sluha, što čini prevalenciju od 3 osobe na 1000 stanovnika $(0,32 \%)$ (Registar osoba s invaliditetom, HZJZ, 2015).

\section{Oštećenja sluha u Hrvatskom registru osoba $s$ invaliditetom}

Oštećenja sluha kao uzrok invaliditeta u nešto većem broju zabilježena su u muškaraca (8 047 osoba, 59,1\% svih osoba kod kojih je uzrok invaliditeta oštećenje sluha, odnosno 3,9\%o svih muškaraca) u odnosu na žene (5 562 osobe, 40,9\% svih osoba kod kojih je uzrok invaliditeta oštećenje sluha, odnosno 2,5\% svih žena). Ovaj uzrok invaliditeta zabilježen je u svim dobnim skupinama, s tim da je najveći broj osoba u dobnoj skupini $\geq 85$ godina ( $23,7 \%$ o svih osoba $\geq 85$ godina), a najmanji u dobnoj skupini 0-4 godine (75 osoba, $0,5 \%$ svih osoba s oštećenjem sluha, odnosno $0,4 \%$ sve djece od 0-4 godine). U radno sposobnoj dobi (20-64 godine) 6109 osoba ima oštećenje sluha $(44,9 \%$ svih osoba s oštećenjem sluha, odnosno 2,3\%o svih osoba te životne dobi), a u dječjoj dobi (0-19 godina) 1539 osoba (11,3\% svih osoba s oštećenjem sluha, odnosno 1,7\%o sve djece) (Tablica 3 , Slika 1). Najviše osoba s oštećenjem sluha očekivano živi na području Grada Zagreba (1 797), a najmanje u Ličko-senjskoj županiji (151) (Tablica 4). Uspoređujući podatke o broju osoba s oštećenjem sluha u odnosu na ukupan broj stanovnika županije, dolazimo do podatka da je najveći udio osoba s oštećenjem sluha na području Virovitičkopodravske, te Požeško-slavonske županije $(0,53 \%)$, a najmanji u Zadarskoj županiji $(0,16 \%)$ (Tablica 4, Slika 2).

Među oštećenjima sluha koja dovode do invaliditeta, u Registru osoba s invaliditetom glavninu (45\%) zauzimaju provodni (konduktivni) i zamjedbeni (perceptivni) gubitak sluha, koji se prema MKB-10 šifriraju kao H90, te nespecificiran gubitak sluha (46\%), koji se prema MKB-10 šifrira kao H91.9 (Tablica 5) .

Uspoređujući podatke Hrvatskog registra osoba $\mathrm{s}$ invaliditetom i podatke međunarodnih istraživanja nailazimo na velike razlike. Prema hrvatskom registru, samo $0,8 \%$ osoba od 70 i više godina ima poremećaj sluha koji uzrokuje invaliditet, dok u Sjedinjenim Američkim Državama čak 63,1\% osoba te životne dobi ima oštećenje sluha (Lin i sur., 2011). Nadalje, procjenjuje se da je na svjetskoj razini prevalencija oštećenja sluha $1,4 \%$ za djecu od 5 do 14 godina, dok je u Registru evidentirano $0,2 \%$ djece te dobi, za žene starije od 15 godina razlika je još veća $(9,8 \%$ svjetska procjena, $0,3 \%$ RH Registar), a za muškarce starije od 15 godina razlika je najveća (12,2\% procjena svjetske prevalencije, 0,4\% evidentiranih u RH Registru) (Stevens i sur., 2011). Ako bismo primijenili svjetsku prevalenciju oštećenja sluha na $\mathrm{RH}$, dobili bismo više od 214000 ljudi s oštećenjem sluha, što je gotovo 16 puta više od broja ljudi trenutno evidentiranih u hrvatskom registru (13 609 osoba). Većina europskih procjena također upućuje na veću prevalenciju oštećenja sluha nego je zabilježena 


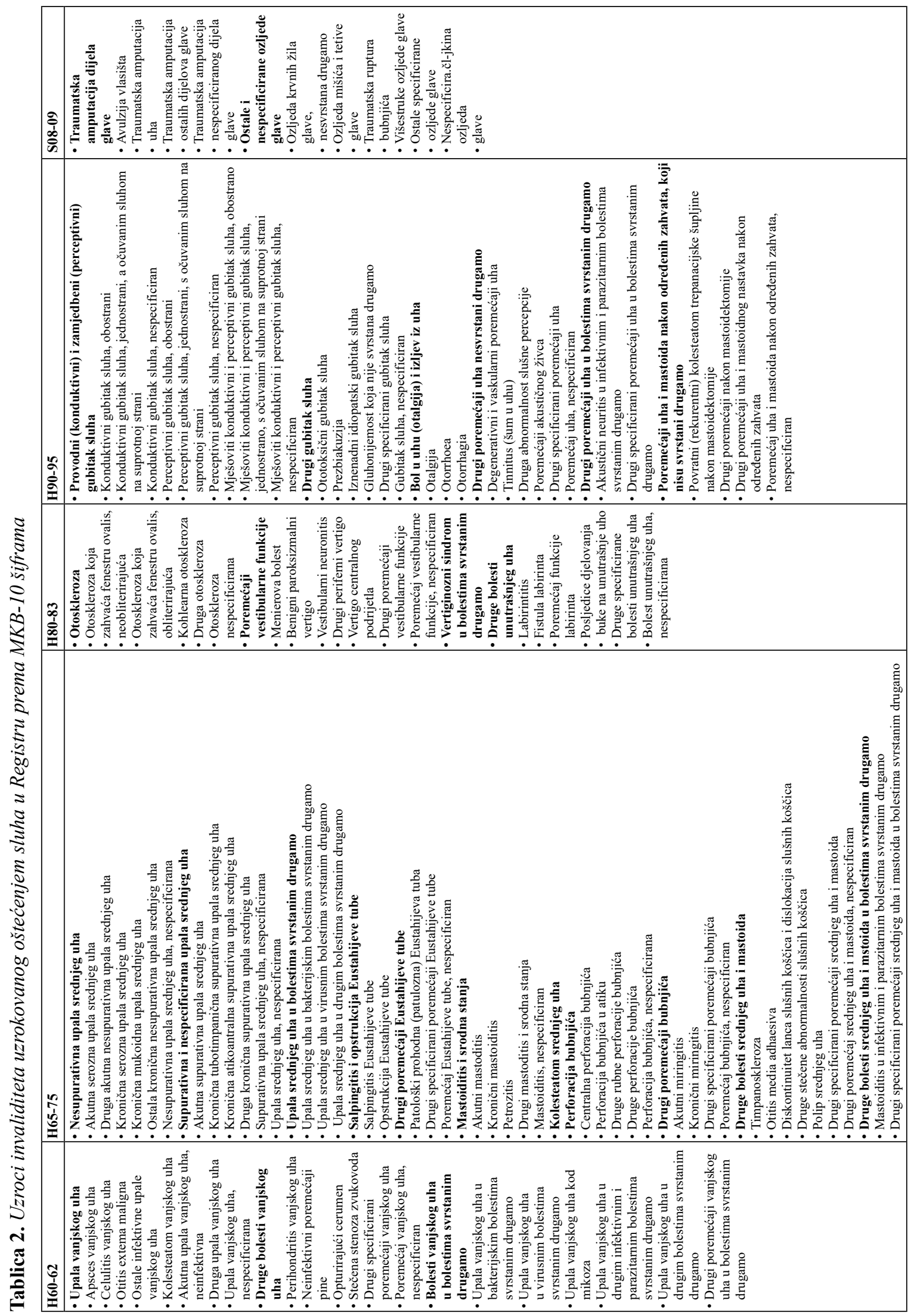


Željka Draušnik, Vesna Štefančić, Tomislav Benjak: Prevalencija invaliditeta uzrokovanog oštećenjem sluha u Republici Hrvatskoj

Tablica 3. Broj osoba s invaliditetom uzrokovanim oštećenjem sluha prema dobi i spolu i udio u ukupnom broju osoba te dobi i spola

\begin{tabular}{|c|c|c|c|c|c|c|}
\hline \multirow{2}{*}{$\begin{array}{c}\begin{array}{c}\text { Dobne } \\
\text { skupine }\end{array} \\
0-4\end{array}$} & \multicolumn{2}{|c|}{$\begin{array}{c}\text { Muškarci } \\
\text { Broj \%o od svih muškaraca te dobi* }\end{array}$} & \multicolumn{2}{|c|}{$\begin{array}{c}\text { Žene } \\
\text { Broj \%o od svih žena te dobi* }\end{array}$} & \multicolumn{2}{|c|}{$\begin{array}{c}\text { Ukupno } \\
\text { Broj \%o od svih osoba te dobi* }\end{array}$} \\
\hline & 44 & 0,4 & 31 & 0,3 & 75 & 0,4 \\
\hline $5-9$ & 169 & 1,6 & 128 & 1,3 & 297 & 1,5 \\
\hline $10-14$ & 343 & 2,8 & 209 & 1,8 & 552 & 2,3 \\
\hline $15-19$ & 348 & 2,8 & 267 & 2,2 & 615 & 2,5 \\
\hline $20-24$ & 278 & 2,1 & 204 & 1,6 & 482 & 1,8 \\
\hline $25-29$ & 221 & 1,5 & 164 & 1,2 & 385 & 1,3 \\
\hline $30-34$ & 210 & 1,4 & 153 & 1,1 & 363 & 1,2 \\
\hline $35-39$ & 168 & 1,2 & 120 & 0,9 & 288 & 1 \\
\hline $40-44$ & 278 & 1,9 & 126 & 0,9 & 404 & 1,4 \\
\hline $45-49$ & 522 & 3,4 & 140 & 0,9 & 662 & 2,2 \\
\hline $50-54$ & 673 & 4,3 & 211 & 1,3 & 884 & 2,8 \\
\hline $55-59$ & 851 & 5,5 & 314 & 2 & 1165 & 3,7 \\
\hline $60-64$ & 1083 & 8,5 & 393 & 2,7 & 1476 & 5,4 \\
\hline $65-69$ & 895 & 10 & 411 & 3,6 & 1306 & 6,5 \\
\hline $70-74$ & 612 & 6,9 & 391 & 3,2 & 1003 & 4,7 \\
\hline $75-79$ & 487 & 7,3 & 508 & 4,7 & 995 & 5,7 \\
\hline $80-84$ & 465 & 13 & 755 & 10,5 & 1220 & 11,3 \\
\hline$\geq 85$ & 400 & 25,8 & 1037 & 23 & 1437 & 23,7 \\
\hline Ukupno & 8047 & 3,9 & 5562 & 2,5 & 13609 & 3,2 \\
\hline
\end{tabular}

*Za broj stanovnika korišteni su podaci Popisa stanovništva iz 2011. godine (Popis stanovništva, kućanstava i stanova 2011; stanovništvo prema starosti i spolu po naseljima)

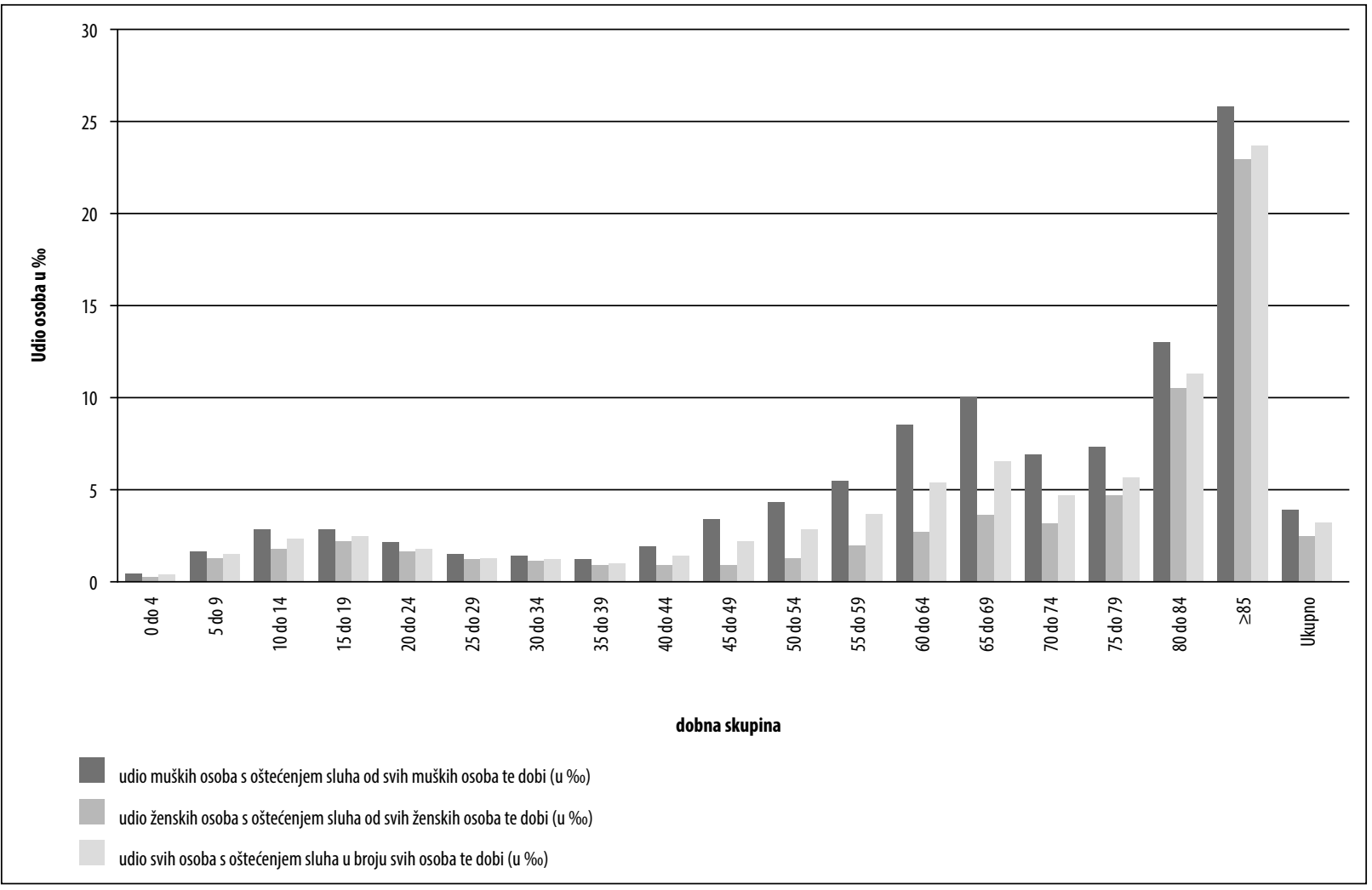

Slika 1. Udio osoba s invaliditetom uzrokovanim oštećenjem sluha prema dobnim skupinama i spolu 
Tablica 4. Broj osoba s invaliditetom uzrokovanim oštećenjem sluha prema županijama prebivališta i njihov udio u ukupnom broju stanovnika županije

\begin{tabular}{|c|c|c|c|c|c|}
\hline Županija & $\begin{array}{c}\text { Muškarci } \\
\text { f }\end{array}$ & $\begin{array}{c}\text { Žene } \\
\text { f }\end{array}$ & $\begin{array}{c}\text { Ukupno } \\
\text { f }\end{array}$ & $\begin{array}{c}\text { Br. stanovnika županije } \\
\text { f }\end{array}$ & $\begin{array}{c}\text { \% od ukupnog broja } \\
\text { stanovnika županije } * * * *\end{array}$ \\
\hline Grad Zagreb & 1011 & 786 & 1797 & 790017 & 0,23 \\
\hline Zagrebačka & 379 & 222 & 601 & 317606 & 0,19 \\
\hline Krapinsko-zagorska & 258 & 191 & 449 & 132892 & 0,34 \\
\hline Sisačko-moslavačka & 518 & 217 & 735 & 172439 & 0,43 \\
\hline Karlovačka & 313 & 308 & 621 & 128899 & 0,48 \\
\hline Varaždinska & 414 & 354 & 768 & 175951 & 0,44 \\
\hline Koprivničko-križevačka & 184 & 124 & 308 & 115584 & 0,27 \\
\hline Bjelovarsko-bilogorska & 233 & 205 & 438 & 119764 & 0,37 \\
\hline Primorsko-goranska & 537 & 512 & 1049 & 296195 & 0,35 \\
\hline Ličko-senjska & 97 & 54 & 151 & 50927 & 0,30 \\
\hline Virovitičko-podravska & 241 & 205 & 446 & 84836 & 0,53 \\
\hline Požeško-slavonska & 245 & 170 & 415 & 78034 & 0,53 \\
\hline Brodsko-posavska & 418 & 242 & 660 & 158575 & 0,42 \\
\hline Zadarska & 164 & 102 & 266 & 170017 & 0,16 \\
\hline Osječko-baranjska & 526 & 305 & 831 & 305032 & 0,27 \\
\hline Šibensko-kninska & 247 & 192 & 439 & 109375 & 0,40 \\
\hline Vukovarsko-srijemska & 288 & 234 & 522 & 179521 & 0,29 \\
\hline Splitsko-dalmatinska & 853 & 517 & 1370 & 454798 & 0,30 \\
\hline Istarska & 240 & 145 & 385 & 208055 & 0,19 \\
\hline Dubrovačko-neretvanska & 203 & 131 & 334 & 122568 & 0,27 \\
\hline Međimurska & 224 & 211 & 435 & 113804 & 0,38 \\
\hline Nepoznato* & 389 & 92 & 481 & l & 1 \\
\hline Ne primjenjuje se** & 49 & 8 & 57 & 1 & 1 \\
\hline Nespecificirano*** & 16 & 35 & 51 & 1 & / \\
\hline Ukupno & 8047 & 5562 & 13609 & 4284889 & $\mathbf{0 , 3 2}$ \\
\hline
\end{tabular}

* Nepoznato - kao mjesto prebivališta osobe navedeno je mjesto po starom šifrarniku naselja, a koje se ne nalazi u službenom šifrarniku naselja

** $\quad$ Ne primjenjuje se - mjesto boravišta izvan $\mathrm{RH}$

*** Nespecificirano - nije navedeno mjesto prebivališta

**** Za ukupan broj stanovnika županija korišteni su podaci Popisa stanovništva iz 2011. godine (Popis stanovništva, kućanstava i stanova 2011; stanovništvo po županijama)

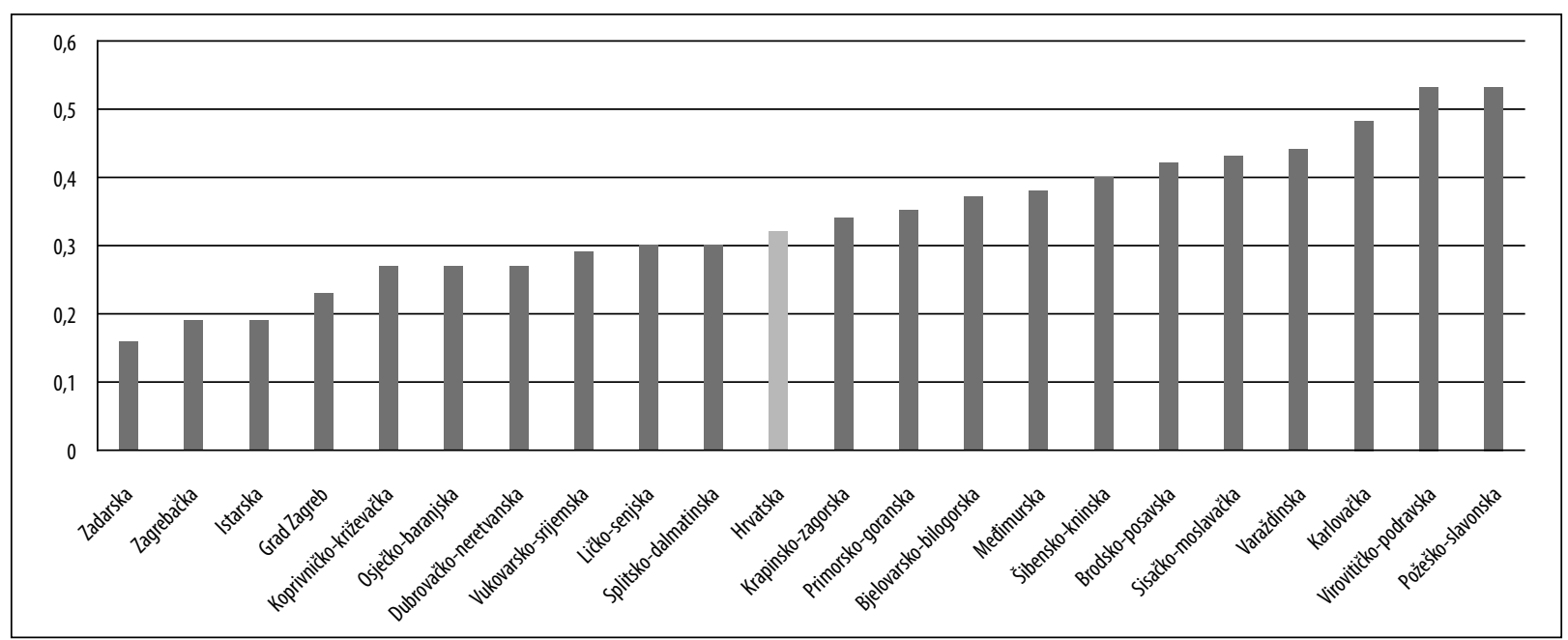

Slika 2. Stopa invaliditeta uzrokovanog oštećenjem sluha prema županijama 
Željka Draušnik, Vesna Štefančić, Tomislav Benjak: Prevalencija invaliditeta uzrokovanog oštećenjem sluha u Republici Hrvatskoj

Tablica 5. Broj osoba s invaliditetom uzrokovanim oštećenjem sluha prema MKB 10 šifri $i$ spolu te njihov udio u ukupnom broju osoba s invaliditetom uzrokovanim oštećenjem sluha prema spolu

\begin{tabular}{|c|c|c|c|c|c|c|}
\hline \multirow{2}{*}{$\begin{array}{l}\text { MKB } 10 \\
\text { Poremećaji vanjskog uha (H60-H62) }\end{array}$} & \multicolumn{2}{|c|}{$\begin{array}{l}\text { Muškarci } \\
\text { Broj \%o }\end{array}$} & \multicolumn{2}{|c|}{$\begin{array}{c}\text { Žene } \\
\text { Broj \%o }\end{array}$} & \multicolumn{2}{|c|}{$\begin{array}{l}\text { Ukupno } \\
\text { Broj \%o }\end{array}$} \\
\hline & 7 & 0,9 & 6 & 1,1 & 13 & 1 \\
\hline Poremećaji srednjeg uha i mastoida (H65-H75) & 115 & 14,3 & 40 & 7,2 & 155 & 11,4 \\
\hline Bolesti unutrašnjeg uha (H80-H83) & 624 & 77,5 & 155 & 27,9 & 779 & 57,2 \\
\hline Ostali poremećaji uha (H90-H95) & 7235 & 899,1 & 5344 & 960,8 & 12579 & 924,3 \\
\hline Provodni (konduktivni) i zamjedbeni (perceptivni) gubitak sluha (H90) & 3467 & 430,8 & 2641 & 474,8 & 6108 & 448,9 \\
\hline Drugi gubitak sluha (H91) & 3637 & 452 & 2604 & 468,2 & 6241 & 458,6 \\
\hline Bol u uhu i izljev iz uha (H92) & 4 & 0,5 & 10 & 1,8 & 14 & 1 \\
\hline Drugi poremećaji uha koji nisu svrstani drugamo (H93) & 109 & 13,5 & 71 & 12,8 & 180 & 13,2 \\
\hline Drugi poremećaji uha u bolestima svrstanima drugamo (H94) & 8 & 1 & 3 & 0,5 & 11 & 0,8 \\
\hline $\begin{array}{l}\text { Poremećaji uha i mastoida nakon određenih zahvata, koji nisu svrstani } \\
\text { drugamo (H95) }\end{array}$ & 10 & 1,3 & 15 & 2,7 & 25 & 1,8 \\
\hline Ozljede (S08-S09) & 66 & 8,2 & 17 & 3 & 83 & 6,1 \\
\hline Ukupno & 8047 & 1000 & 5562 & 1000 & 13609 & 1000 \\
\hline
\end{tabular}

u Hrvatskoj, pa se tako spominju podaci o više od 10\% osoba s oštećenjem sluha (Traynor, 2011), pa čak do oko $16 \%$ stanovništva Europe, odnosno 10,9\% stanovništva EU (55 milijuna ljudi) (Shield, 2006). Iz ovih podataka je vidljiva višestruka razlika u udjelu osoba s oštećenjem sluha u ukupnoj populaciji između RH i zemalja EU i Europe, pa čak i između podataka različitih istraživača za istu populaciju (NIDCD, 2015, Agrawal i sur., 2008).

Dva su glavna razloga navedenim razlikama. Prvi je metodološko definiranje "oštećenja sluha". Naime, u Hrvatski registar osoba s invaliditetom ulaze samo podaci za teže oblike oštećenja sluha koji dovode do invaliditeta, dok SZO i ostala navedena istraživanja obuhvaćaju sve stupnjeve oštećenja, uključujući i blaža koja ne dovode do invaliditeta. Drugi razlog su metodološke razlike svjetskih istraživanja i hrvatskog istraživanja, pri čemu su rezultati međunarodnih istraživanja utemeljeni na procjenama, dok se hrvatsko istraživanje bazira na prikupljanju podataka temeljem rješenja o invaliditetu.

Za kreiranje usporedive, valjane i pouzdane statistike o invaliditetu općenito, trebala bi se uvelike poboljšati međunarodna usporedivost statističkih podataka o invaliditetu, te na taj način unaprijediti razumijevanje invaliditeta u svijetu, a za to je potrebno razvijanje niza odgovarajućih metoda (Madans i Loeb, 2013, McDermott i Turk, 2011, Mont, 2007., Roth, 2011).
Ukoliko se uzmu u obzir razlike u prevalencijama oštećenja sluha koje uzrokuju invaliditet, kao i broj osoba koje imaju taj invaliditet, nameće se zaključak kako oštećenje sluha kao javnozdravstveni problem ima velike implikacije u ekonomskom i socijalnom smislu. Postoje podaci koji govore o procijenjenim troškovima oštećenja sluha u Europi od oko 213 milijardi $€$ (Shield, 2006, Rothisur., 2011).

Budući da podaci u Registru značajno odstupaju od svjetskih istraživanja i procjena, postavlja se pitanje je li trenutno postojeća registracija značajnih oštećenja sluha, koja se bazira na nalazima $i$ mišljenjima tijela vještačenja i utvrđivanja invaliditeta, dostatna za potpuni obuhvat ove skupine osoba s invaliditetom? Budući da su najčešće liječnici primarne zdravstvene zaštite prvi koji dolaze u kontakt s osobom koja ima poremećaj sluha, trebalo bi poraditi i na njihovoj edukaciji o načinima prijave tih osoba u Registar. Također, trebalo bi olakšati osobama s oštećenjem sluha pristup informacijama, te ih upoznati s njihovim pravima $\mathrm{i}$ uputiti na sustav vještačenja koji je temelj za registriranje invaliditeta u RH, što je jedan od temelja za korištenje njihovih prava.

U Republici Hrvatskoj je od 30.12.2014. g. na snazi Zakon o profesionalnoj rehabilitaciji i zapošljavanju osoba s invaliditetom (NN, 157/13 i NN, 152/14), prema kojem su poslodavci (u javnom, ali i u privatnom sektoru) obveznici zapošljavanja osoba s invaliditetom ukoliko imaju 20 i više zapo- 
slenika. Broj osoba s invaliditetom koje je poslodavac obvezan zaposliti ovisi o broju zaposlenih i o djelatnosti koju obavlja, a u slučaju neispunjavanja ove obveze, dužan je platiti novčanu naknadu zbog neispunjavanja kvote za zapošljavanje osoba $\mathrm{s}$ invaliditetom. Shodno tome, primijećeno je da od 01.01.2015. g. dolazi do povećanja broja prijava osoba s invaliditetom koje pristižu u Registar, a za očekivati je da će taj broj i dalje rasti. Navedena zakonska mjera govori u prilog nužnosti promjena koje bi dovele do povećanja potpunog obuhvata u prikupljanju podataka o osobama s oštećenjima sluha koja dovode do invaliditeta.

\section{ZAKLJUČAK}

Prema podacima Hrvatskog registra za osobe s invaliditetom, u RH trenutno ima 13609 osoba s invaliditetom uzrokovanim oštećenjem sluha, od kojih najveći broj osoba (12 579) ima oštećenje iz MKB-10 grupe ostalih poremećaja uha (H90-H95) i čine $92,43 \%$ osoba s invaliditetom uzrokovanim oštećenjem sluha. U toj grupi poremećaja najčešći su poremećaji uzrokovani provodnim (konduktivnim) i zamjedbenim (perceptivnim) gubitkom sluha (H90) - 45,86\% svih osoba s invaliditetom uzrokovanim oštećenjem sluha te drugim gubitkom sluha (H91) - ukupno 44,89\% svih osoba s invaliditetom uzrokovanim oštećenjem sluha.

Velik javnozdravstveni statistički problem u svijetu predstavlja neusporedivost podataka o oštećenjima sluha između zemalja s visokim i niskim dohocima. Za valjanu i pouzdanu usporedbu podataka o invaliditetu, trebala bi se uvelike poboljšati i unificirati metodologija prikupljanja i obrade podataka o invaliditetu, te na taj način kontinuirano pridonositi kreiranju afirmativnih javnozdravstvenih politika invaliditeta u svijetu. Kako bi se metodologije prikupljanja i obrade podataka unaprijedile, na razini $\mathrm{RH}$ potrebno je ažurirati protokole za kontinuirana praćenja oštećenja sluha u populaciji, što je značajno obuhvatnije od registriranja podataka o osobama s oštećenjima sluha koja dovode do invaliditeta, ali i usporedive s međunarodnim podacima i rezultatima međunarodnih istraživanja. Upravo bi adekvatna izmjena legislativnog okvira rezultirala nužnim promjenama koje bi dovele do povećanja potpunog obuhvata u prikupljanju podataka o osobama s oštećenjima sluha koje dovode do invaliditeta, a sve u svrhu unaprjeđenja kvalitete života tih osoba.

Mjere koje bi pridonijele smanjenju opterećenja bolestima iz skupine oštećenja sluha u RH zasigurno su programi probira na oštećenje sluha, edukacija osoba o štetnosti izlaganju preglasnim zvukovima, povećanje svjesnosti o postojanju i primjeni ototoksičnih lijekova, genetska preventivna savjetovanja, poticanje standardiziranog sakupljanja podataka o prevalenciji oštećenja sluha u svim dobnim skupinama u svrhu analiza poput ove, koje bi kod donosioca odluka rezultirale kreiranjem javnozdravstvenih politika unaprjeđenja zdravlja osoba s oštećenjem sluha. 


\section{LITERATURA}

Agrawal, Y., Platz, E.A., Niparko, J.K. (2008): Prevalence of Hearing Loss and Differences by Demographic Characteristics Among US Adults - Data From the National Health and Nutrition Examination Survey, 1999-2004. Posjećeno 24.12.2015. dostupno na mrežnoj stranici: http://archinte.jamanetwork.com/article. aspx?articleid $=414406$.

Al-Mahbashi, M.Y., Raja'a, Y.A. (2011): Quality of life among adult Yemeni patients with hearing loss. Med. J. Cairo Univ., Vol. 79, No. 2, March: 157-161.

Dobie, R.A., Van Hemel, S.B., urednici (2004): Hearing loss - Determining Eligibility for Social Security Benefits. Washington DC: National Research Council.

Hearing Loss Association of America. Types, Causes and Treatment. Posjećeno 06.10.2015. dostupno na mrežnoj stranici Američke udruge za gubitak sluha:

http://www.hearingloss.org/content/types-causes-and-treatment.

Lin, F.R., Thorpe R., Gordon-Salant S., Ferrucci L. (2011): Hearing loss prevalence and risk factors among older adults in the United States. J Gerontol A Biol Sci Med Sci(2011) 66A (5): 582-590. DOI: 10.1093/gerona/glr002.

Madans, J.H., Loeb, M. Methods to improve international comparability of census and survey measures of disability. Disabil Rehabil. 2013 Jun;35(13):1070-3. DOI: 10.3109/09638288.2012.720353. Epub 2012 Oct 1. Posjećeno 06.10.2015. dostupno na mrežnoj stranici: http://www.ncbi.nlm.nih.gov/pubmed/23020151.

McDermott, S., Turk, M.A. The myth and reality of disability prevalence: measuring disability for research and service. Disabil Health J. 2011 Jan;4(1):1-5. DOI: 10.1016/j.dhjo.2010.06.002. Epub 2010 Nov 5. Posjećeno 06.10.2015. dostupno na mrežnoj stranici: http://www.ncbi.nlm.nih.gov/pubmed/21168800.

Međunarodna klasifikacija bolesti i srodnih zdravstvenih problema (2012). Deseta revizija, drugo izdanje. Zagreb; Medicinska naklada.

Mont, D. (2007): Measuring disability prevalence. SP Discussion Paper No. 0706. Posjećeno 06.10.2015. dostupno na mrežnoj stranici: http://siteresources.worldbank.org/DISABILITY/Resources/Data/MontPrevalence.pdf .

National Institute on Deafness and Other Communication Disorders (2015). Posjećeno 24.12.2015. dostupno na mrežnoj stranici: http://www.nidcd.nih.gov/health/statistics/pages/quick.aspx.

Podaci preuzeti iz Registra osoba s invaliditetom, Službe za javno zdravstvo, Hrvatskog zavoda za javno zdravstvo, 2015.

Popis stanovništva, kućanstava i stanova 2011; stanovništvo po županijama. Posjećeno 06.10.2015. dostupno na mrežnoj stranici Državnog zavoda za statistiku: http://www.dzs.hr/Hrv/censuses/census2011/results/censustabshtm. htm.

Roth, T.N., Hanebuth, D., Probst, R. (2011): Prevalence of age-related hearing loss in Europe: a review. Arch Otorhinolaryngol, 268:1101-1107.

Shield, B. (2006): Evaluation of the social and economic costs of hearing impairment. A report for Hear-it. Posjećeno 06.10.2015. dostupno na mrežnoj stranici: http://www.hear-it.org.

Stevens, G., Flaxman, S., Brunskill, E., Mascarenhas, M., Mathers, C.D., Finucane, M. (2011): Global and regional hearing impairment prevalence: an analysis of 42 studies in 29 countries. Posjećeno 24.12.2015. dostupno na mrežnoj stranici: http://eurpub.oxfordjournals.org/content/early/2011/12/24/eurpub.ckr176.

Škrbić, R., Milankov V., Veselinović M., Todorović A. (2013):Uticaj oštećenja sluha na kvalitet života adolescenata, Med Pregl, LXVI (1-2): 32-39.

Traynor,R. The Incidence of Hearing Loss Around the World, 2011. Posjećeno 06.10.2015. dostupno na mrežnoj stranici: http://hearinghealthmatters.org/hearinginternational/2011/incidence-of-hearing-loss-around-the-world/.

Uredba o metodologijama vještačenja: Narodne novine, br. 153/2014. 
WHO global estimates on prevalence of hearing loss; Mortality and Burden of Diseases and Prevention of Blindness and Deafness. World Health Organization, 2012. Posjećeno 06.10.2015. dostupno na mrežnoj stranici World Health Organization: http://www.who.int/pbd/deafness/WHO_GE_HL.pdf.

World Health Organization. Deafness and Hearing Loss. (2012) Posjećeno 06.10.2015. dostupno na mrežnoj stranici World Health Organization: http://www.who.int/mediacentre/factsheets/fs300/en/.

Zakon o Hrvatskom registru o osobama s invaliditetom: Narodne novine, br. 64/ 2001.

Zakon o profesionalnoj rehabilitaciji i zapošljavanju osoba s invaliditetom: Narodne novine, br. 157/2013 i Narodne novine, br. 152/2014.

\section{THE PREVALENCE OF DISABILITY CAUSED BY HEARING IMPAIRMENTS IN THE REPUBLIC OF CROATIA}

\footnotetext{
Abstract: The number of hearing impaired persons in Croatia is monitored by the Registry of Persons with Disabilities. The data in the Registry are submitted by doctors, the relevant ministries, and the Croatian Pension Insurance Institute. According to the Registry, there are 13,609 people in Croatia whose disability is caused by a hearing loss (0.32\%), but compared to the data of international research, we encounter significant differences. In fact, if we compare this data with the global prevalence of hearing impairments, the international percentage rate is nearly 16 times higher than the Croatian rate based on those currently registered in the Croatian Registry. Other international assessments also point to a higher prevalence of hearing impairments than recorded in Croatia. One of the main reasons for these differences is the degree of hearing impairments that is taken into account. The Croatian Registry monitors the number of people among whom the hearing impairment led to disability, while international research includes also milder forms, which do not cause disability. Another, equally important reason is the fact that international research is based on estimates, while in Croatia accurate data, based on disability diagnoses, are being used.
}

Key words: hearing impairment, disability prevalence, Registry of Persons with Disabilities 